\title{
Work Personality (Wave), Intelligence and the Dark Side at Work
}

\author{
Kat Palaiou', Jackie Sykes ${ }^{2}$, Chris Welford ${ }^{2}$, Adrian Furnham ${ }^{1,3}$ \\ ${ }^{1}$ Research Department of Clinical, Educational and Health Psychology, University College London, London, UK \\ ${ }^{2}$ Sixth Sense Consulting, London, UK \\ ${ }^{3}$ Norwegian Business School (BI), Nydalveien, Olso, Norway \\ Email: a.furnham@ucl.ac.uk
}

How to cite this paper: Palaiou, K., Sykes, J., Welford, C., \& Furnham, A. (2016). Work Personality (Wave), Intelligence and the Dark Side at Work. Psychology, 7, 1531-1544. http://dx.doi.org/10.4236/psych.2016.713149

Received: August 25, 2016

Accepted: November 7, 2016

Published: November 10, 2016

Copyright $\odot 2016$ by authors and Scientific Research Publishing Inc. This work is licensed under the Creative Commons Attribution International License (CC BY 4.0).

http://creativecommons.org/licenses/by/4.0/ (c) (i) Open Access

\begin{abstract}
This study examined the relationship between the "bright" and "dark" side of work personality, as well as their relationship to cognitive ability. In all 374 working adults completed three tests at work: Hogan Development Survey (HDS) (Hogan \& Hogan, 2009); Saville Consulting Wave Professional Styles (Saville Consulting, 2005); Raven's Progressive Matrices (Raven, Raven, \& Court, 1998). The four behavioural clusters (Thought, Influence, Adaptability, Delivery) of the "bright side" test were independent of one another. Three of the four correlations between intelligence and personality were significant. Regressions showed that gender, intelligence, and the "dark side" factors measured at facet and higher order levels accounted for between $7 \%$ and $37 \%$ of the variance. The thought cluster was best predicted by intelligence and high scores on Leisurely, Bold and Imaginative. The influence cluster was best predicted by intelligence (negatively), skeptical, reserved (negative) and colourful. The adaptability cluster was most related to diligence (negatively). Finally, delivery was predicted by intelligence (negatively), excitability (negatively), skeptical and diligence. Limitations and implications are considered.
\end{abstract}

\section{Keywords}

Dark and Bright Side Personality, Intelligence, Work Personality, Gender

\section{Introduction}

Organisational scientists have spent the last 20 years, trying to identify which are the ingredients that make a senior manager successful. Research has shown that intelligence and personality traits play a vital role on predicting major life outcomes, such work performance (Barrick \& Mount, 1991; Judge, Higgins, Thoresen, \& Barrick, 1999). 
Further, organisational researchers have started to investigate the dark side of personality and work achievement/promotion/experience (Furnham, Crump, \& Ritchie, 2013; Spain, Harms, \& Lebreton, 2013).

The aim of this study is to investigate behaviours related to workplace, like capability, with the dark side of personality while controlling for intelligence and gender. There have been a number of studies looking at the relation between the "bright" and the "dark" side personality and its connection with work success (Furnham, Hyde, \& Trickey, 2012a) as well as the relationship between personality and intelligence (ChamorroPremuzic \& Furnham, 2005a). This study looks at the relation of intelligence and "dark" side personality to workplace personality as assessed by a relatively new, but validated test.

The Wave Professional Styles (Wave) have its foundation on a hierarchical model of occupational personality that is based on the Five Factor Model (FFM) (Costa Jr. \& McCrae, 1990) and Great Eight (Bartram, 2005). The wave has four behavioural clusters: thought, influence, adapting and delivery (Table 1). It measures a broad spectrum of work behaviours from personality to motives, talents, preferred culture and competency potential (McDowall \& Kurz, 2007). These are conceived of as independent behavioural clusters, which reflect particular work-related competencies.

The Hogan Development Survey (HDS) (Hogan \& Hogan, 2001) was used to measure "dark side" traits. The HDS obtains 11 subclinical traits and uses positive softened naming instead of the more negative termed in DSM-IV (see Table 2) (Spain et al., 2013). Factorial analysis has shown that these 11 subscales are separated in three clusters known as moving against (bold, mischievious, colourful, imaginative), moving towards (diligent and dutiful) and moving away from others (excitable, cautious, skeptical, reserved, leisurely) (Furnham \& Trickey, 2011; Khoo \& Burch, 2008).

Intelligence is measured by using Raven's Progressive Matrices (Raven, 1990/2000) which is one of the most established, validated and celebrated measures of cognitive ability. Since the end of World War I, the measure of general mental ability (GMA) or

Table 1. The correspondence of the four wave behavioural clusters with the great eight and a combination of five factor model with psychological concepts.

\begin{tabular}{|c|c|c|}
\hline $\begin{array}{l}\text { Wave } \\
\text { behavioural clusters }\end{array}$ & Great eight competencies & $\begin{array}{l}\text { Five factor model with } \\
\text { psychological concepts }\end{array}$ \\
\hline \multirow[t]{2}{*}{ Thought } & Analysing \& interpreting & Intelligence \\
\hline & Creating \& conceptualising & Openness to experience \\
\hline \multirow[t]{2}{*}{ Influence } & Interacting \& presenting & Extraversion \\
\hline & Leading \& deciding & Need for power \\
\hline \multirow[t]{2}{*}{ Adaptability } & Supporting \& coping & Agreeableness \\
\hline & Adapting \& coping & Emotional stability \\
\hline \multirow[t]{2}{*}{ Delivery } & Organising \& executing & Conscientiousness \\
\hline & Enterprising \& performing & Need for achievement \\
\hline
\end{tabular}

Description was taken from McDowall \& Kurz (2007: p. 303). 
Table 2. Overlapping themes from HDS and DMS-IV Axis II.

\begin{tabular}{|c|c|c|c|}
\hline DSM-IV & Definition & HDS scales & Definition \\
\hline Borderline & $\begin{array}{l}\text { Inappropriate anger; } \\
\text { unstable and intense } \\
\text { relationships. }\end{array}$ & Excitable & $\begin{array}{l}\text { Moody and inconsistent } \\
\text { concerns being enthusiastic } \\
\text { about persons ideas, and } \\
\text { projects and then becoming } \\
\text { disappointed in them. }\end{array}$ \\
\hline Paranoid & $\begin{array}{l}\text { Distrustful and suspicious } \\
\text { of others; motives of } \\
\text { others are interpreted } \\
\text { negatively. }\end{array}$ & Skeptical & $\begin{array}{l}\text { Cynical, distrustful, overly } \\
\text { sensitive to criticism, and } \\
\text { skeptical of others' } \\
\text { true intensions. }\end{array}$ \\
\hline Avoidant & $\begin{array}{l}\text { Social inhibition; feelings } \\
\text { of inadequacy and } \\
\text { hypersensitivity to } \\
\text { criticism or rejection. }\end{array}$ & Cautious & $\begin{array}{l}\text { Reluctant to take risks for fear } \\
\text { of being rejected or negatively } \\
\text { evaluated. }\end{array}$ \\
\hline Schizoid & $\begin{array}{l}\text { Emotional coldness and } \\
\text { detachment from } \\
\text { socialrelationships; } \\
\text { indifferent to } \\
\text { praise and criticism. }\end{array}$ & Reserved & $\begin{array}{l}\text { Aloof, detached and } \\
\text { uncommunicative; lacking } \\
\text { interest in or awareness of the } \\
\text { feelings of others. }\end{array}$ \\
\hline Passive-Aggressive & $\begin{array}{l}\text { Passive resistance to } \\
\text { adequate social and } \\
\text { occupational } \\
\text { performance; irritated } \\
\text { when asked to } \\
\text { do something he/she } \\
\text { does not want to. }\end{array}$ & Leisurely & $\begin{array}{l}\text { Independent; ignoring people's } \\
\text { requests and becoming irritated } \\
\text { or argumentative if they persist. }\end{array}$ \\
\hline Narcissistic & $\begin{array}{l}\text { Arrogant and haughty } \\
\text { behaviours or } \\
\text { attitudes, grandiose } \\
\text { sense of self-importance } \\
\text { and entitlement. }\end{array}$ & Bold & $\begin{array}{l}\text { Unusually self-confident; } \\
\text { feelings of grandiosity and } \\
\text { entitlement; over valuation } \\
\text { of one's capabilities. }\end{array}$ \\
\hline Antisocial & $\begin{array}{l}\text { Disregard for the truth; } \\
\text { impulsivity and failure to } \\
\text { plan ahead; failure } \\
\text { to conform }\end{array}$ & Mischievous & $\begin{array}{l}\text { Enjoying risk taking and testing } \\
\text { the limits; needing excitement; } \\
\text { manipulative, deceitful, cunning } \\
\text { and exploitative. }\end{array}$ \\
\hline Histrionic & $\begin{array}{c}\text { Excessive emotionality } \\
\text { and attention seeking; self } \\
\text { dramatising, theatrical and } \\
\text { exaggerated } \\
\text { emotional expression. }\end{array}$ & Colourful & $\begin{array}{l}\text { Expressive, animated and } \\
\text { dramatic; wanting to be } \\
\text { noticed and needing to } \\
\text { be the centre of attention. }\end{array}$ \\
\hline Schizotypal & $\begin{array}{l}\text { Odd beliefs or magical } \\
\text { thinking; behaviour } \\
\text { or speech that is odd, } \\
\text { eccentric or peculiar. }\end{array}$ & Imaginative & $\begin{array}{c}\text { Acting and thinking in creative } \\
\text { and sometimes odd or } \\
\text { unusual ways. }\end{array}$ \\
\hline
\end{tabular}


Continued

\begin{tabular}{|c|c|c|c|}
\hline $\begin{array}{l}\text { Obsessive- } \\
\text { Compulsive }\end{array}$ & $\begin{array}{l}\text { Preoccupations with } \\
\text { orderliness; rules, } \\
\text { perfectionism and control; } \\
\text { over Conscientiousness and } \\
\text { inflexible. }\end{array}$ & Diligent & $\begin{array}{c}\text { Meticulous, precise and } \\
\text { perfectionistic, } \\
\text { inflexible about rules and } \\
\text { procedures; critical of others. }\end{array}$ \\
\hline Dependent & $\begin{array}{l}\text { Difficulty making everyday } \\
\text { decisions without excessive } \\
\text { advice and reassurance; } \\
\text { difficulty expressing } \\
\text { disagreement out of } \\
\text { fear of loss of support } \\
\text { or approval. }\end{array}$ & Dutiful & $\begin{array}{l}\text { Eager to please and reliant on } \\
\text { others for support and } \\
\text { guidance; reluctant to take } \\
\text { independent action or to go } \\
\text { against popular opinion. }\end{array}$ \\
\hline
\end{tabular}

Note: Description was taken from HDS manual (Hogan \& Hogan, 2009) and Spain et al. (2013: p. 4).

intelligence has an important role, in the workplace, especially for hiring employees (Yerkes, 1921). Schmidt \& Hunter (2004) found that the correlation range of GMA and job success/performance is from .31 to .73 .

Many studies have examined personality correlates of work success (Furnham, 2008; Hurtz \& Donovan, 2000). Judge et al. (1999) found in relation to occupational level and income that conscientiousness has a positive relation .51 and .53 , openness to experience .26 and .32 and neuroticism -.26 and -.34 respectively. Studies suggest that conscientiousness is usually the most powerful predictor of all work outcome measures and that together the Big Five factors together may account for between $10 \%$ and $30 \%$ of the variance. For instance, Furnham et al. (2013) recently demonstrated that conscientiousness, more than any trait or intelligence was the strongest predictor of speed of promotion.

Various studies have examined the relationship between well-known and established personality measures and "dark" side factors (Furnham et al., 2013; Furnham \& Crump, 2005). Furnham and Crump (2005) found that neuroticism is predicted by high scores in excitable, skeptical, cautious, leisurely, imaginative, diligent and dutiful and by low scores in reserved, mischievous and colourful. Extraversion is predicted by high scores in bold, mischievous, colourful and imaginative and by low scores in cautious, reserved and diligent. Openness to experience is predicted by high scores in bold, mischievous, colourful and imaginative and by low scores in leisurely. Agreeableness is predicted by high scores in cautious and dutiful and by low scores in excitable, skeptical, reserved, bold, mischievous, colourful and imaginative. Finally, conscientiousness is predicted by high scores in skeptical, bold, colourful and diligent and by low scores in mischievous and imaginative.

Many studies have revealed, perhaps paradoxically, that some "dark" side personality traits are potentially beneficial at work (Furnham \& Trickey, 2011; Furnham, Hyde, \& Trickey, 2014). More specifically, diligent predicts an individual with high integrity and low counterwork productivity scores, bold is commonly found in many successful CEOs (Chatterjee \& Hambrick, 2007). Colourful is positive associated with potential 
(Furnham et al., 2012a) as well speed of promotion (Furnham et al., 2013) Mischievous is positively linked with stress tolerance and sales potential (Furnham, Hyde, \& Trickey, 2012 b) and promotion is positively related with diligent and dutiful (Race, Hyde, \& Furnham, 2012).

This study will explore the extent to which the four behavioural clusters of wave are predicted by the dark side of personality while controlling for intelligence and gender. According to the Wave model, thought is associated with openness; influence with extraversion and agreeableness, adaptability with neuroticism and delivery with conscientiousness. Based on previous studies in this area, but using different measurements, it is predicted that imaginative is most associated with thought, colourful with influence, excitable with adaptability and diligence with delivery. It is also predicted that intelligence is positively correlated with thought but negatively correlated with delivery (Furnham et al., 2013).

\section{Method}

\subsection{Participants}

In all 374 employees of a UK company took part in this study. Due to missing data on HDS, Ravens and Wave, only 181 were considered where 33 (18.2\%) were females. The age of the participants was not collected.

\subsection{Materials}

Hogan Development Survey (HDS) (Hogan \& Hogan, 2009). HDS is a self-administered personality questionnaire that focuses on personality disorders occupying the psychological space halfway between psychopathology and normal personality, which means that it allows for a dimensional approach to the research. It includes 154 items that are dichotomous (true-false). The coefficient alphas were ranging from .5 to .7 with the average alpha coefficient being .64. In the test-retest reliabilities for sample of 60 participants over a three-month interval the range were between .5 and .8 , having an average of .68.

The Raven's Progressive Matrices (Ravens). Ravens assesses problem-solving and reasoning ability (Raven, Raven, \& Court, 1998) and has been used to more than 45 countries on samples totalling over 240,000 participants (Brouwers, Van de Vigver, \& Van Hemert, 2009). The test has 48 items. Each item of this test is consisted by a pattern of diagrammatic puzzles with one piece missing. Ravens helps identify an individual's potential for success in positions like executive, director, general manager or similar professional positions in an organization. The internal validity is .85 in U.S standardisation sample $(N=929)$ (Raven, 1990/2000).

Wave Professional Styles. Saville Consulting Wave Professional Styles is an online, self-report measure that was based on the personality model of the Five Factor Model (Costa Jr. \& McCrae, 1990) and on the competency model of Great Eight (Bartram, 2005). It has 36 Professional Style dimensions that are divided to four hierarchical factors, called behaviour clusters (Thought, Influence, Adaptability and Delivery). Each 
hierarchical factor/cluster contains three sections and each section is consisting by three dimensions. In total there are 12 sections (see Appendix) (Rojon \& McDowall, 2010). In the current study, we will use the four clusters. Wave is used for workplace purposes like recruitment, talent management, and different kinds of development such as team, organisational, personal and coaching. Jayne, Small and Oxley (2006) found internal consistency reliabilities with a mean of .78 and an average corrected validity of .32. Wave has been translated to more than 15 languages and undergone crosscultural validation to ensure the underlying constructs have remained robust (Saville Consulting, 2005).

\subsection{Procedure}

Participants were tested by Sixth Sense Consultancy. The participants were given personal feedback on their scores. There anonymised scores were used in this analysis with their consent. They were nearly all employed as middle to senior managers in British company. They took this test as part of an assessment exercise. Inevitably, this could have affected their results because of issues such as impression management and general dissimulation.

\section{Results}

\section{Data Analysis}

First we explored the reliability of the WAVE measure and inter-correlations between the scales. Then we looked at the correlations between the four WAVE scales and the Dark Side traits at both facet and domain level as well as intelligence. Finally we computed a number of regressions to exam the incremental validity of dark side personality over gender and intelligence.

Descriptive statistics of the Wave, Cronbach's Alpha and the inter-correlations of the four clusters are presented in Table 3. When dealing with psychological constructs values below 7 can be realistically expected due to the diversity of the constructs being measure (Kline, 1999). As shown in Table 3, the highest Cronbach's Alpha is .66 and the lowest is .55, which means that the $66 \%-55 \%$ is considered as true variance. All the four values at Cronbach's Alpha are considered relatively low but expected (Kline, 1999).

Table 3. Descriptive statistics, cronbach's alpha and correlation of the four wave behavioural clusters.

\begin{tabular}{|c|c|c|c|c|c|c|c|}
\hline \multirow{2}{*}{$\begin{array}{l}\text { Behavioural } \\
\text { clusters }\end{array}$} & \multirow{2}{*}{ Mean } & \multirow{2}{*}{$\mathrm{SD}$} & \multirow{2}{*}{$\begin{array}{c}\text { Cronbach's } \\
\text { alpha }\end{array}$} & \multicolumn{4}{|c|}{ Correlation } \\
\hline & & & & 1 & 2 & 3 & 4 \\
\hline Thought & 56.73 & 8.51 & .66 & - & -.04 & .12 & .02 \\
\hline Influence & 57.07 & 7.53 & .65 & & - & $.20^{\star *}$ & .04 \\
\hline Adaptability & 53.88 & 7.88 & .57 & & & - & -.10 \\
\hline Delivery & 55.32 & 6.65 & .55 & & & & - \\
\hline
\end{tabular}

Note. The numbers in the row under the title "Behavioural Clusters", correspond to the numbers of the columns. $N=181,{ }^{* *} p<.01$. 
With regards to the inter-correlations, there is only one significant small positive correlation between Influence and Adaptability, showing the four factors are, as hypothesised, independent of one another.

Descriptive statistics of the HDS, the three clusters of HDS and Ravens as well as and their correlation with the four behavioural clusters of Wave are presented in Table 4. Thought has seven small positively significant values ranging from .15 to .26 . Influence has three small and two moderate positive correlations ranging from .19 to .58 . Furthermore, Influence has also three negative small correlations ranging from -.16 to -.24 . Adaptability has six small to moderate negative correlations ranging from -.19 to -.30 and three small positive correlations ranging from .16 to .23. Finally, on Delivery there is a small negative correlation of -.20 and four positive correlations ranging from .15 to .48 . All hypotheses were confirmed.

A series of hierarchical regressions were performed using the four clusters of Wave as dependent variables and HDS, gender and intelligence (Ravens) as independent variables. The results are presented in Table 5.

In step 1 of the hierarchical regression, we controlled for gender and intelligence that accounted for $1.2 \%$ of the variance of predicting work behaviours (i.e. motives, talents, preferred culture and competency potential) for Thought, $1.8 \%$ for Influence, $.9 \%$ for Adaptability and $2.8 \%$ for Delivery. Ravens was significant in all clusters but Adaptability. Ravens has a negative relation with Delivery and Influence but a positive relation with Thought.

Table 4. Descriptive statistics of HDS, Three clusters of HDS, Ravens and their correlation with the four Wave behavioural clusters.

\begin{tabular}{ccccccc}
\hline & & & \multicolumn{4}{c}{ Correlations with wave } \\
\cline { 5 - 7 } & Mean & SD & Thought & Influence & Adaptability & Delivery \\
\hline Excitable & 51.43 & 25.66 & .02 & .02 & $-.20^{* *}$ & -.14 \\
Skeptical & 56.94 & 26.91 & .09 & $.19^{* *}$ & -.09 & $.24^{* *}$ \\
Cautious & 44.34 & 24.17 & .04 & $-.18^{*}$ & $-.19^{* *}$ & -.08 \\
Reserved & 51.24 & 26.84 & $.18^{*}$ & $-.24^{* *}$ & $-.17^{*}$ & .06 \\
Leisurely & 51.19 & 26.74 & $.26^{* *}$ & -.03 & -.11 & .02 \\
Bold & 58.22 & 26.86 & $.18^{*}$ & $.22^{* *}$ & .08 & $.15^{*}$ \\
Mischievous & 58.18 & 28.59 & -.04 & $.30^{* *}$ & .14 & .01 \\
Colourful & 56.27 & 27.73 & -.07 & $.58^{* *}$ & $.23^{* *}$ & -.09 \\
Imaginative & 54.38 & 27.40 & $.19^{*}$ & .14 & $.16^{*}$ & -.03 \\
Diligent & 55.9 & 26.40 & .13 & -.12 & $-.30^{* *}$ & $.48^{* *}$ \\
Dutiful & 54.81 & 27.62 & .09 & -.08 & .03 & -.08 \\
Moving against & 227.04 & 78.47 & .09 & $.44^{* *}$ & $.21^{* *}$ & .01 \\
Moving away & 255.13 & 77.75 & $.22^{* *}$ & -.08 & $-.25^{* *}$ & .04 \\
Moving towards & 110.71 & 38.01 & $.16^{*}$ & -.14 & $-.19^{*}$ & $.27^{* *}$ \\
Ravens & 50.57 & 28.1 & $.15^{*}$ & $-.16^{*}$ & .05 & $-.20^{* *}$ \\
\hline
\end{tabular}

Note: $N=181,{ }^{*} p<.05,{ }^{* *} p<.01$. 
Table 5. Hierarchical regressions with Gender and Ravens entered at step 1 and HDS at step 2 of the four Wave Behavioural clusters.

\begin{tabular}{|c|c|c|c|c|c|c|c|c|}
\hline & \multicolumn{2}{|c|}{ Thought } & \multicolumn{2}{|c|}{ Influence } & \multicolumn{2}{|c|}{ Adaptability } & \multicolumn{2}{|c|}{ Delivery } \\
\hline \multirow[t]{2}{*}{ Step 1} & \multicolumn{2}{|c|}{$F(2,178)=2.13$} & \multicolumn{2}{|c|}{$F(2,178)=2.65$} & \multicolumn{2}{|c|}{$F(2,178)=.19$} & \multicolumn{2}{|c|}{$F(2,178)=3.56$} \\
\hline & \multicolumn{2}{|c|}{$\mathrm{R}^{2} \mathrm{adj}=.012$} & \multicolumn{2}{|c|}{$\mathrm{R}^{2} \mathrm{adj}=.018$} & \multicolumn{2}{|c|}{$\mathrm{R}^{2} \mathrm{adj}=-.009$} & \multicolumn{2}{|c|}{$\mathrm{R}^{2} \mathrm{adj}=.028$} \\
\hline \multirow[t]{3}{*}{ Step 2} & \multicolumn{2}{|c|}{$F(13,167)=3.16$} & \multicolumn{2}{|c|}{$F(13,167)=9.09$} & \multicolumn{2}{|c|}{$F(13,167)=3.45$} & \multicolumn{2}{|c|}{$F(13,167)=6.35$} \\
\hline & \multicolumn{2}{|c|}{$\mathrm{R}^{2} \mathrm{adj}=.14$} & \multicolumn{2}{|c|}{$\mathrm{R}^{2} \mathrm{adj}=.37$} & \multicolumn{2}{|c|}{$\mathrm{R}^{2} \mathrm{adj}=.15$} & \multicolumn{2}{|c|}{$\mathrm{R}^{2} \mathrm{adj}=.28$} \\
\hline & $\beta$ & $t$ & $\beta$ & $t$ & $\beta$ & $t$ & $\beta$ & $t$ \\
\hline Gender (step 1) & -.67 & -.43 & -.75 & -.57 & .07 & .05 & -.20 & -.16 \\
\hline Ravens (step 1) & .04 & $2.00^{*}$ & -.04 & $-2.24^{*}$ & .01 & .61 & -.05 & $-2.66^{* *}$ \\
\hline Excitable & .03 & 1.31 & -.02 & -.08 & -.05 & -1.96 & -.06 & $-2.96^{* *}$ \\
\hline Skeptical & -.01 & -.54 & .04 & $2.08^{*}$ & -.002 & -.07 & .05 & $2.72^{* *}$ \\
\hline Cautious & -.04 & -1.50 & -.01 & -.54 & -.03 & -1.60 & -.05 & -.21 \\
\hline Reserved & .04 & 1.96 & -.03 & $-2.02^{*}$ & -.03 & -1.49 & .02 & 1.35 \\
\hline Leisurely & .06 & $2.67^{* *}$ & -.05 & -.27 & -.007 & -.29 & -.02 & -1.13 \\
\hline Bold & .06 & $2.20^{*}$ & -.01 & -.58 & .003 & .10 & .09 & .48 \\
\hline Mischievous & -.03 & -1.47 & .02 & 1.43 & .02 & .72 & .05 & .30 \\
\hline Colourful & -.04 & -1.58 & .13 & $7.17^{* * *}$ & .02 & .90 & -.05 & -.29 \\
\hline Imaginative & .06 & $2.36^{*}$ & -.01 & -.77 & .04 & 1.87 & -.02 & -1.16 \\
\hline Diligent & .02 & .82 & -.02 & -1.07 & -.09 & $-3.94^{* * *}$ & .11 & $6.44^{* * *}$ \\
\hline Dutiful & .01 & .68 & .03 & .16 & .02 & 1.12 & .03 & .19 \\
\hline Gender (step 2) & -.24 & -.18 & -.01 & -.93 & -1.08 & -.73 & .41 & .37 \\
\hline Ravens (step 2) & .04 & $2.00^{*}$ & -.04 & $-2.40^{*}$ & -.005 & -.024 & -.03 & -1.86 \\
\hline
\end{tabular}

Note: $N=181,{ }^{*} p<.05,{ }^{* *} p<.01,{ }^{* *} p<.001$.

In step 2, the HDS explained an additional $12.8 \%$ of the variance, with higher values on Leisurely, Bold and Imaginative significantly predicting work behaviours for Thought. Ravens was still a significant predictor suggesting that the high intelligence has a positive relation with Thought. With regards to Influence, an additional $35.2 \%$ of variance was explained with both higher values on Skeptical and Colourful but lower values on Reserved significantly predicting work behaviours. Ravens is still a significant predictor suggesting that the high intelligence has a negative relation with Influence. An additional $14.1 \%$ of variance was explained with lower values on Diligent significantly predicting work behaviours for Adaptability. Finally, an additional $25.2 \%$ of variance was explained when HDS was added with both higher values on Skeptical and Diligent but lower values on Excitable significantly predicting work behaviours for Delivery. Ravens is no longer a significant predictor suggesting that high intelligence is not as important as the dark side of personality for this cluster.

Finally, we also conducted a series hierarchical regressions using the four clusters of Wave as criterion variables, the three clusters/higher order factors of HDS, gender and intelligence as predictor variables. The results are presented in Table 6. 
Table 6. Hierarchical regressions with Gender and Ravens entered at step 1 and the three clusters of HDS of the four Wave behavioural clusters.

\begin{tabular}{|c|c|c|c|c|c|c|c|c|}
\hline & \multicolumn{2}{|c|}{ Thought } & \multicolumn{2}{|c|}{ Influence } & \multicolumn{2}{|c|}{ Adaptability } & \multicolumn{2}{|c|}{ Delivery } \\
\hline \multirow[t]{2}{*}{ Step 1} & \multicolumn{2}{|c|}{$F(2,178)=2.13$} & \multicolumn{2}{|c|}{$F(2,178)=2.65$} & \multicolumn{2}{|c|}{$F(2,178)=.19$} & \multicolumn{2}{|c|}{$F(2,178)=3.56$} \\
\hline & \multicolumn{2}{|c|}{$\mathrm{R}^{2} \mathrm{adj}=.012$} & \multicolumn{2}{|c|}{$\mathrm{R}^{2} \mathrm{adj}=.018$} & \multicolumn{2}{|c|}{$\mathrm{R}^{2} \mathrm{adj}=-.009$} & \multicolumn{2}{|c|}{$\mathrm{R}^{2} \mathrm{adj}=.028$} \\
\hline \multirow[t]{3}{*}{ Step 2} & \multicolumn{2}{|c|}{$F(13,167)=3.76$} & \multicolumn{2}{|c|}{$F(13,167)=11.24$} & \multicolumn{2}{|c|}{$F(13,167)=5.67$} & \multicolumn{2}{|c|}{$F(13,167)=4.55$} \\
\hline & \multicolumn{2}{|c|}{$\mathrm{R}^{2} \mathrm{adj}=.07$} & \multicolumn{2}{|c|}{$\mathrm{R}^{2} \mathrm{adj}=.22$} & \multicolumn{2}{|c|}{$\mathrm{R}^{2} \mathrm{adj}=.12$} & \multicolumn{2}{|c|}{$\mathrm{R}^{2} \mathrm{adj}=.09$} \\
\hline & $\beta$ & $t$ & $\beta$ & $t$ & $\beta$ & $t$ & $\beta$ & $t$ \\
\hline Gender (Step 1) & -.67 & -.43 & -.75 & -.57 & .07 & .05 & -.20 & -.16 \\
\hline Ravens (Step 1) & .04 & $2.00^{*}$ & -.04 & $-2.24^{*}$ & .01 & .61 & -.05 & $-2.66^{* *}$ \\
\hline Moving Against & .01 & 1.20 & .04 & $6.64^{* * *}$ & .02 & $3.29 * *$ & .02 & .35 \\
\hline Moving Away & .02 & $2.69^{* *}$ & -.01 & -1.75 & -.03 & $-3.47^{* *}$ & -.03 & -.43 \\
\hline Moving Towards & -.03 & 1.76 & -.02 & -1.32 & -.03 & -1.82 & .05 & $3.88^{* * *}$ \\
\hline Gender (Step 2) & -.31 & -.20 & -1.49 & -1.27 & -.82 & -.56 & -.18 & -.15 \\
\hline Ravens (Step 2) & .05 & $2.33^{*}$ & -.04 & $-2.31^{*}$ & .01 & .54 & -.046 & $-2.77^{* *}$ \\
\hline
\end{tabular}

Note: $N=181,{ }^{*} p<.05,{ }^{* *} p<.01,{ }^{* *} p<.001$.

In step 1 of the hierarchical regression, we controlled for gender and intelligence (Ravens) that accounted for $1.2 \%$ of variance for work behaviours for Thought, $1.8 \%$ for Influence, $.9 \%$ for Adaptability and $2.8 \%$ for Delivery. As above, Ravens was significant with all clusters but Adaptability, showing a positive relation with Thought but a negative relation with Influence and Delivery.

In step 2, the three clusters of HDS were added and an additional 5.8\% of variance was explained with higher order values on moving away from others significantly work behaviours for Thought. Furthermore, Ravens was still a significant predictor suggesting that the high intelligence has a positive relation with Thought. An additional 20.2\% of variance was explained with higher values on moving against others significantly predicting work behaviours for Influence. Noteworthy is that Ravens is still a significant predictor suggesting that the high intelligence has a negative relation with Influence. With regards to Adaptability an extra $11.1 \%$ of variance was explained with higher values on moving against others but lower values on moving away from others significantly predicting work behaviours. Finally, an additional $6.2 \%$ of variance was explained with higher values on moving towards others significantly predicting work behaviours for Delivery. Ravens was still a significant predictor suggesting that the high intelligence has a negative relation with Delivery.

\section{Discussion}

The aim of this study was to investigate the relationship of the four behavioural clusters of Wave and the dark side of personality while controlling for intelligence and gender. Gender was not a significant predictor in any of analyses in any step, whereas intelligence was a significant predictor, even if after we controlled for it. We found that high scores on intelligence predicted Thought and low scores on intelligence predicted In- 
fluence in both analyses. A possible explanation may lie in the relation of intelligence and FFM. More specifically, Thought is based on intelligence and Openness to Experience. Openness to Experience is the most consistent replicated finding that shows by far the strongest link with intelligence (DeYoung, 2011). The meta-analysis of Ackerman and Heggestad (1997) revealed a moderate correlation of .33. Consequently, it is reasonable that intelligence remained significant predictor at Step 2 in both analyses. Influence is based on Extraversion and need for power. According to DeYoung (2011), studies published since 2000 present a weak negative correlation between Extraversion and intelligence $(r=-.04)$, which might explain our finding.

With regards to Delivery, intelligence was a significant predictor in Step 2 only when the three clusters of HDS were entered. A possible explanation might be that since moving towards others contains Diligent, Ravens was influenced by it. Diligent was the most significant scale predicting Delivery. Furthermore, Delivery contains Conscientiousness and need for achievement. Conscientiousness is the best predictor for academic achievement and has a small negative relation with intelligence around -.12 (Moutafi, Furnham, \& Crump, 2003; Furnham \& Chamorro-Premuzic, 2005). Chamorro-Premuzic and Furnham (2005a) proposed that the high scores in conscientiousness in individuals with lower intelligence is a compensatory mechanism; that is more intelligent people need to be less organised and hard-working because they are more efficient. It is possible that the combination of Conscientiousness and Diligent lead Ravens to be a significant predictor on Delivery.

With regards to the dark side of personality, our findings revealed that high scores on Leisurely, Bold and Imaginative predicted Thought. High scores in Openness to Experience predicted Bold and Imaginative however both Furnham and Crump (2005) and Furnham et al. (2013) found low scores of Openness to Experience predict Leisurely where in the current study we found the opposite. A possible explanation might be that Thought is also a combination of three primary sectors and nine dimensions and not such a "clean" measure of Openness.

Influence was predicted by low scores in Reserved and high scores in Skeptical and Colourful. As shown in Table 1, Influence is based on Extraversion and the need for power. Furnham and Crump (2005) and Furnham et al. (2013) found that high scores in Extraversion predicted Colourful and low scores predicted Reserved but they did not find anything for Skeptical. Spain et al. (2013) implied that in HDS, Machiavellianism corresponds to Skeptical. A Machiavellian personality has a need for power; he/she manipulates, lies to and exploits others, in order to satisfy his/her own agenda (Spain et al., 2013; Wu \& LeBreton, 2011). Therefore, it is not surprising that high scores in Skeptical predicted Influence.

Adaptability was predicted by low scores in Diligent. One of the constructs of Adaptability is Emotional Stability, which the negative pole of Neuroticism. Our results, which show highscore in Neuroticism predicts Diligent and Cautious, confirms the work of Furnham and Crump (2005) and Furnham et al. (2013). Finally, low scores in Excitable and high scores in Diligent and Skeptical predict Delivery. Furnham and 
Crump (2005), and Furnham et al. (2013) found that high scores in Conscientiousness predict Diligent and Skeptical. Furthermore, they found a significant negative correlation of Excitable with Conscientiousness. The negative correlation combined with the fact that Delivery has three sections and nine dimensions might justify our finding.

Despite numerous technical and in-house reports as well as the widespread use of the Wave instrument for selection and coaching in the United Kingdom, few studies have looked at its psychometric properties and correlates. This study showed that, on the basis of its theoretical construction it was possible to test and confirm various hypotheses as to the relationship between the four clusters and intelligence and "dark" side traits.

\section{Conclusion}

The current study, as many others, has some limitations. The most important limitation is that the Cronbach's alpha of the Wave is very low and that the results should be interpreted very carefully. Another limitation is that the age of the participants is unknown which we could not control. Furthermore, the method invariance is problematic with most of the occupational studies (Furnham et al., 2012a). All the measurements were self-reports that lead to two main problems; first there is a tendency of an increase of the reported size of the relations (correlations) and social desirability. Ideally we would have had some objective work performance measure as a criterion.

\section{References}

Ackerman, P. L., \& Heggestad, E. D. (1997). Intelligence, Personality, and Interests: Evidence for Overlapping Traits. Psychological Bulletin, 121, 219-245. http://dx.doi.org/10.1037/0033-2909.121.2.219

Barrick, M. R., \& Mount, M. K. (1991). The Big Five Personality Dimensions and Job Performance: A Meta-Analysis. Personnel Psychology, 44, 1-26. http://dx.doi.org/10.1111/j.1744-6570.1991.tb00688.x

Bartram, D. (2005). The Great Eight Competencies: A Criterion-Centric Approach to Validation. Journal of Applied Psychology, 90, 1185-1203. http://dx.doi.org/10.1037/0021-9010.90.6.1185

Brouwers, S. A., Van de Vijver, F. J. R., \& Van Hemert, D. A. (2009). Variation in Raven's Progressive Matrices Scores across Time and Place. Learning and Individual Differences, 19, 330338. http://dx.doi.org/10.1016/j.lindif.2008.10.006

Chamorro-Premuzic, T., \& Furnham, A. (2005a). Personality and Intellectual Competence. Mahwah, NJ: Lawrence Erlbaum Associates.

Chatterjee, A., \& Hambrick, D. (2007). It's All about Me: Narcissistic Chief Executive Officers and Their Effects on Company Strategy and Performance. Administrative Science Quarterly, 52, 351-386.

Costa Jr., P. T., \& McCrae, R. R. (1990). The NEO Personality Inventory Manual. Odessa, FL: Psychological Assessment Resources.

DeYoung, C. G. (2011). Intelligence and Personality. In R. J. Sternberg, \& S. B. Kaufman (Eds.), The Cambridge Handbook of Intelligence (pp. 711-737). New York: Cambridge University Press. http://dx.doi.org/10.1017/CBO9780511977244.036

Furnham, A. (2008). Personality and Intelligence at Work. London: Routledge. http://dx.doi.org/10.4324/9780203938911 
Furnham, A., \& Chamorro-Premuzic, T. (2005). Personality, Intelligence, and Art. Personality and Individual Differences, 36, 705-715. http://dx.doi.org/10.1016/S0191-8869(03)00128-4

Furnham, A., \& Crump, J. (2005). Personality Traits, Types and Disorders: An Examination of the Relationship between Three Self-Report Measures. European Journal of Personality, 19, 167-184. http://dx.doi.org/10.1002/per.543

Furnham, A., \& Trickey, G. (2011). Sex Differences in the Dark Side Traits. Personality and Individual Differences, 50, 517-522. http://dx.doi.org/10.1016/j.paid.2010.11.021

Furnham, A., Crump, J., \& Ritchie, W. (2013). What It Takes: Ability, Demographic, Bright and Dark Side Trait Correlates of Years to Promotion. Personality and Individual Differences, 55, 952-956. http://dx.doi.org/10.1016/j.paid.2013.07.469

Furnham, A., Hyde, G., \& Trickey, G. (2012a). Bright Aspects to Dark Side Traits: Dark Side Traits Associated with Work Success. Personality and Individual Differences, 52, 908-913. http://dx.doi.org/10.1016/j.paid.2012.01.025

Furnham, A., Hyde, G., \& Trickey, G. (2012b). Do Your Dark Side Traits Fit? Dysfunctional Personalities in Different Work Sectors. Applied Psychology, 63, 589-606. http://dx.doi.org/10.1111/apps.12002

Furnham, A., Hyde, G., \& Trickey, G. (2014). The Dark Side of Career Preference: Dark Side Traits, Motives and Values. Journal of Applied Social Psychology, 44, 106-114. http://dx.doi.org/10.1111/jasp.12205

Hogan, R., \& Hogan, J. (2001). Assessing Leadership: A View from the Dark Side. International Journal of Selection and Assessment, 9, 40-51. http://dx.doi.org/10.1111/1468-2389.00162

Hogan, R., \& Hogan, J. (2009). Hogan Development Survey Manual (3rd ed.). Tulsa, OK: Hogan Assessment Systems.

Hurtz, G. M., \& Donovan, J. J. (2000). Personality and Job Performance: The Big Five Revisited. Journal of Applied Psychology, 85, 869-879. http://dx.doi.org/10.1037/0021-9010.85.6.869

Jayne, S., Small, C., \& Oxley, H. (2006). Wave Focus Organisational Feedback Report. Total Standardisation Pilot Group. Jersey (UK): Saville Consulting Group.

Judge, T. A., Higgins, C. A., Thoresen, C. J., \& Barrick, M. R. (1999). The Big Five Personality Traits, General Mental Ability, and Career Success across the Life Span. Personnel Psychology, 52, 621-652. http://dx.doi.org/10.1111/j.1744-6570.1999.tb00174.x

Khoo, H., \& Burch, G. (2008). The "Dark Side" of leadership Personality and Transformational Leadership. Personality and Individual Differences, 44, 86-97. http://dx.doi.org/10.1016/j.paid.2007.07.018

Kline, P. (1999). The Handbook of Psychological Testing (2nd ed.). London: Routledge.

McDowall, A., \& Kurz, R. (2007). Making the Most of Psychometric Profiles-Effective Integration into the Coaching Process. International Coaching Psychology Review, 2, 299-309.

Moutafi, J., Furnham, A., \& Crump, J. (2003). Demographic and Personality Predictors of Intelligence: A Study Using the NEO-Personality Inventory and the Myers-Briggs Type Indicator. European Journal of Personality, 17, 79-94. http://dx.doi.org/10.1002/per.471

Race, M.-C., Hyde, G., \& Furnham, A. (2012). Dark Side Traits and Promotion at Work: What Gets You up the Greasy Pole? Manuscript under review.

Raven, J. et al. (1990/2000). Manual for Raven's Progressive Matrices and Vocabulary Scales. Research Supplement No. 3 (2nd/3rd Edition): A Compendium of International and North American Normative and Validity Studies Together with a Review of the Use of the RPM in Neuropsychological Assessment. Oxford, England: Oxford Psychologists Press; San Antonio, TX: The Psychological Corporation. 
Raven, J., Raven, J. C., \& Court, J. H. (1998). Raven Manual: Section 4, Advanced Progressive Matrices, 1998 Edition. Oxford, UK: Oxford Psychologists Press Ltd.

Rojon, C., \& McDowall, A. (2010). Cultural Orientation Framework (COF) Assessment Questionnaire in Cross-Cultural Coaching: A Cross-Validation with Wave Focus Style. International Journal of Evidence Based Coaching and Mentoring, 8, 1-26.

Saville Consulting (2005). Saville Consulting Wave. Technical Document. Jersey, UK: Saville Consulting Group.

Schmidt, F. L., \& Hunter, J. E. (2004). General Mental Ability in the World of Work: Occupational Attainment and Job Performance. Journal of Personality and Social Psychology, 86, 162173. http://dx.doi.org/10.1037/0022-3514.86.1.162

Spain, S. M., Harms, P., \& Lebreton, J. M. (2013). The Dark Side of Personality at Work. Journal of Organizational Behaviour, 35, S41-S60. http://dx.doi.org/10.1002/job.1894

Wu, J., \& LeBreton, J. M. (2011). Reconsidering the Dispositional Basis of Counterproductive Work Behavior: The Role of Aberrant Personality Traits. Personnel Psychology, 64, 593-626. http://dx.doi.org/10.1111/j.1744-6570.2011.01220.x

Yerkes, R. M. (Ed.) (1921). Psychological Examining in the U.S. Army: Memoirs of the National Academy of Sciences (Vol. 15). Washington DC: U.S. Government Printing Office. 


\section{Appendix}

The four clusters of Wave containing the 12 sections and the 36 dimensions.

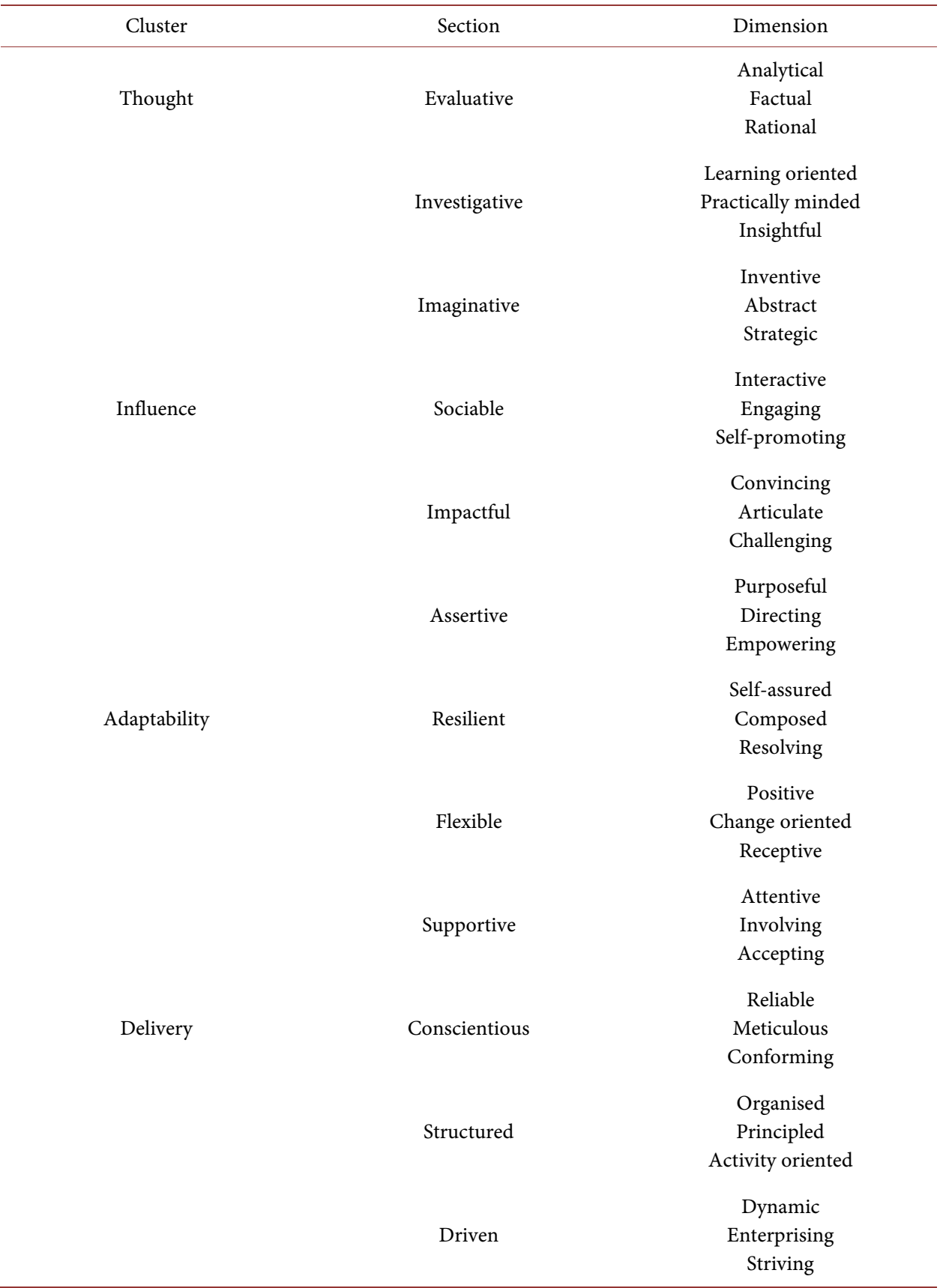


Submit or recommend next manuscript to SCIRP and we will provide best service for you:

Accepting pre-submission inquiries through Email, Facebook, LinkedIn, Twitter, etc. A wide selection of journals (inclusive of 9 subjects, more than 200 journals)

Providing 24-hour high-quality service

User-friendly online submission system

Fair and swift peer-review system

Efficient typesetting and proofreading procedure

Display of the result of downloads and visits, as well as the number of cited articles

Maximum dissemination of your research work

Submit your manuscript at: http://papersubmission.scirp.org/

Or contact psych@scirp.org 